\title{
Odpowiedź na recenzję Michała Kurana
}

W „Zagadnieniach Rodzajów Literackich” 2020 z. 3 Michał Kuran ogłosił recenzję Kroniki, to jest historyi świata Marcina Bielskiego (t. 1-3, oprac. Dariusz Śnieżko, Dorota Kozaryn, przy współudziale Eleny Karczewskiej, Wydawnictwo Naukowe Uniwersytetu Szczecińskiego, Szczecin 2019). Autorowi dziękuję za trud włożony w zapoznanie się z tą obszerną edycją, za uwagi merytoryczne i życzliwy ton jego opinii. Zarazem - jako kierownik zespołu badawczego - czuję się zobowiązany do sprostowania informacji, które mogą wprowadzić w błąd czytelnika niezorientowanego w kontekście edytorskim lub niezaznajomionego z tym wydaniem. W czterech punktach.

\section{I}

Na stronach $157-158$ autor pisze:

O trwałym znaczeniu tego dzieła dla kultury polskiej świadczą edycje: Franciszka Bohomolca z roku 1764, ogłoszona w Warszawie przez Antoniego Gałęzowskiego z lat 1829-1833 w Zbiorze Pisarzów Polskich (t. 11-19) i wydana w Sanoku przez Kazimierza Józefa Turowskiego z 1856 roku w ramach Biblioteki Polskiej (z. 55-82). Ze względu na swą wartość i charakter dzieło ukazywało się więc w zaborach rosyjskim i austriackim. Wszystkie bez wyjątku edycje łączy monumentalny rozmach wymuszony znaczną objętością dzieła. Na tym bogatym tle pracę Dariusza Śnieżki i Doroty Kozaryn wyróżnia obszerny komentarz, Wstęp wydawców (t. 1, s. 7-42), Stownik wyrazów dawnych (t. 3, s. 451-498) oraz Wykaz nazw geograficznych (t. 3, s. 499-586).

Otóż — wbrew temu, co pisze Michał Kuran — wymienione wyżej edycje NIE SĄ wydaniami kroniki uniwersalnej Marcina Bielskiego, tylko wznowieniami Kroniki polskiej, jaką 
w 1597 wydał jego syn Joachim. Była to znacząco przeredagowana i kontynuowana (do śmierci Batorego) wersja jednej tylko, „polskiej” księgi historii powszechnej spisanej przez Marcina Bielskiego - i to też imię, imię ojca, Joachim zamieścił na karcie tytułowej, swoje drukując niżej, ale wyraźnie: „Nowo przez Joachima Bielskiego, syna jego wydana”. Zadbał też o adekwatny do zawartości tytuł: Kronika polska. Imię Joachima zniknęło jednak z kart tytułowych w wydaniach Bohomolca, Gałęzowskiego i Turowskiego, co bywa źródłem pomyłek katalogowo-bibliograficznych, ale po przewróceniu paru kart (lub po paru kliknięciach w bibliotece cyfrowej) dobrze już wiadomo, z jakim tekstem mamy do czynienia. W związku z tym edycje te nie są bynajmniej „bogatym tłem” (jak pisze Michał Kuran) dla wydania szczecińskiego, przeciwnie: jest ono pierwszym od 1564 roku i kompletnym wznowieniem Kroniki, to jest historyi świata Marcina Bielskiego.

\section{II}

Upominając się o indeks nazw osobowych, a także lokalizacje dla Stownika wyrazów dawnych i Wykazu nazw geograficznych, autor recenzji na stronie 158 wskazuje dobre przykłady: „Zestawienia, o których piszę, są standardowo stosowane w edycjach wychodzących w seriach: «Biblioteka Pisarzy Staropolskich», jak również «Biblioteka Dawnej Literatury Popularnej i Okolicznościowej». Inni wydawcy powinni naśladować to rozwiązanie”. W rzeczywistości „standard” jest urozmaicony: „Biblioteka Pisarzy Staropolskich” standardowo wyposaża edycje w lokalizowane słowniki wyrazów archaicznych, natomiast indeksy nazw własnych nie są obecne w każdym wydaniu składającym się na tę doskonałą serię. Nie wszystkie edycje w znamienitej serii „Biblioteka Dawnej Literatury Popularnej i Okolicznościowej” zaopatrzone są w indeks osobowy czy słownik wyrazów archaicznych. Dla uzupełnienia obrazu dodam, że taki stan rzeczy przedstawia równie zasłużona „Bibliotheca Curiosa”. Spostrzeżenia w sprawie tendencji dominujących i uzasadnień dla działań takich bądź innych, to byłby odrębny temat, wymagający zniuansowanego podejścia. Michał Kuran jednak formułuje jednoznaczne i - w tej jednoznaczności — nieodpowiadające faktom uogólnienie. Dla leksemu „standard” przyjmuję pierwsze znaczenie ze Słownika Języka Polskiego PWN: „Poziom towarów lub usług, zwłaszcza spełniający podstawowe wymagania" i takie znaczenie odczytuję w sformułowaniu Autora recenzji.

\section{III}

Na stronie 160 autor recenzji pisze na temat fragmentu Wstępu wydawców: „Badacz [Dariusz Śnieżko] podjął również temat pochodzenia i funkcji materiału ilustracyjnego; natomiast zasygnalizował jedynie problem istnienia różnic pomiędzy kolejnymi edycjami dzieła. Nie poprowadził szczegółowej prezentacji tych zmian”. A sprawy mają się następująco: kolejne edycje są omawiane na przestrzeni stron od 10 do 14 - w zakresie ram wydawniczych, przemian kompozycyjnych i modyfikacji założeń uzasadniających te przemiany, włączania nowego materiału (drugie wydanie jest dwa razy obszerniejsze od pierwszego, a na przestrzeni trzech wydań liczba ksiąg kroniki podwoiła się); potem dopiero następuje już bardziej szczegółowe przedstawienie edycji ostatniej, przyjętej za podstawę wydawniczą. Użyta przez Michała Kurana fraza „zasygnalizował jedynie” nie znajduje zatem potwierdzenia w zawartości omawianego przezeń Wstępu wydawców. 
IV

Na tejże stronie 160 recenzent powołuje się na rzekomą wypowiedź autorów opracowania: „Choć ich edycja, jak deklarują w części trzeciej wstępu, ma charakter popularnonaukowy [...]”. Oświadczam, że taka deklaracja nie padła, a określenie „popularnonaukowy” (w jakiejkolwiek formie gramatycznej) nie zostało przez nas użyte ani razu. Edycja, zgłoszona jako projekt naukowy do konkursu w Narodowym Programie Rozwoju Humanistyki, jako projekt naukowy została zrecenzowana, przyjęta i rozliczona.

\section{DARIUSZ ŚNIEŻKo}

(iD) https://orcid.org/0000-0003-0247-9900

Uniwersytet Szczeciński

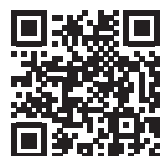

